\title{
PENGAWASAN MASYARAKAT TERHADAP PELAKSANAAN PEMILU LEGISLATIF TAHUN 2014 DI KABUPATEN PANGKEP
}

\author{
Nasaruddin, ${ }^{1}$ Ansyari Mone ${ }^{2}$, dan Hamrun ${ }^{1}$ \\ ${ }^{1}$ Program Studi Ilmu Pemerintahan Fakultas Ilmu Sosial dan Ilmu Politik \\ Universitas Muhammadiyah Makassar \\ Jl Sultan Alauddin No 259 Makassar 90221 \\ Telp. 0411-866972 ext. 107. Fax. 0411-8655888 \\ nasaruddin@yahoo.co.id, hamrun07@gmail.com \\ ${ }^{2}$ Program Studi Ilmu Adminitrasi Negara Fakultas Ilmu Sosial dan Ilmu Politik \\ Universitas Muhammadiyah Makassar \\ Jl Sultan Alauddin No 259 Makassar 90221 \\ Telp. 0411-866972 ext. 107. Fax. 0411-8655888 \\ ansyarimone@live.com
}

\begin{abstract}
The purpose of this study was to determine the supervision by the public to the legislative elections in 2014 in Pangkep. This type of research that is qualitative, as well as data collection was performed using observation and interview techniques. The results showed: public scrutiny of legislative elections in 2014, through direct supervision is done by visiting and performing in locations where objects are monitored as: DPT, campaigning, voting and counting; and Direct supervision is not done without visiting the place of work or object of the supervision is to access the documents of the election by the executive committee elections. This is done to create a fair election, clean, honest and democratic.
\end{abstract}

Keywords: surveillance society, elections, legislative

\begin{abstract}
ABSTRAK
Tujuan penelitian ini adalah untuk mengetahui pengawasan yang dilakukan oleh masyarakat terhadap pemilihan umum anggota legislatif tahun 2014 di Kabupaten Pangkep. Tipe penelitian yakni kualitatif, serta pengumpulan data dilakukan menggunakan teknik observasi dan wawancara. Hasil penelitian menunjukkan: pengawasan masyarakat terhadap pemilu legislatif 2014, melalui pengawasan langsung dilakukan dengan cara mendatangi dan melakukan pemeriksaan di tempat terdapat objek yang diawasi seperti: DPT, kampanye, pemungutan suara dan perhitungan suara; dan pengawasan tidak Langsung yaitu dilakukan tanpa mendatangi tempat pelaksanaan pekerjaan atau objek yang diawasi yaitu mengakses dokumen-dokumen pelaksanaan pemilu melalui panitia pelaksana pemilu. Hal ini dilakukan untuk menciptakan pemilu yang adil, bersih, jujur dan demokratis.
\end{abstract}

Kata Kunci: pengawasan masyarakat, pemilu, legislatif 


\section{A. PENDAHULUAN}

Untuk menjamin agar pemilu berjalan sesuai dengan ketentuan dan asas pemilu, diperlukan suatu pengawalan terhadap jalannya setiap tahapan pemilu. Dalam konteks pengawasan pemilu di Indonesia, pengawasan terhadap proses pemilu dilembagakan dengan adanya lembaga Badan Pengawas Pemilu (Bawaslu). Pengawasan dari Bawaslu adalah bentuk pengawasan yang terlembaga dari suatu organ Negara.

Disamping pengawasan oleh Bawaslu, terdapat juga pengawasan yang dilakukan oleh masyarakat terhadap proses penyelenggaraan pemilu yang disebut dengan kegiatan pemantuan pemilu. Adanya partisipasi masyarakat dalam melakukan pengawasan pemilu ini adalah bentuk dari penggunaan hak warga negara untuk mengawal hak pilihnya. Kemudian, kegiatan pemantauan ini juga merupakan upaya kontrol dari publik untuk menjaga suara dan kedaulatan rakyat di dalam penyelenggaraan Negara.

Sebagaimana

diamanatkan

Undang-undang Dasar Negara Republik Indonesia Tahun 1945, kemerdekaan berserikat, berkumpul dan mengeluarkan pendapat merupakan hak asasi manusia yang harus dilaksanakan untuk memperkuat semangat kebangsaan dalam Nagara Kesatuan Republik Indonesia yang demokratis. Hak untuk berserikat dan berkumpul ini kemudian diwujudkan dalam pembentukan partai politik sebagai sala satu pilar demokrasi dalam sistem politik indonesia.

Di alam demokrasi pengawasan masyarakat diperlukan dalam pengelolaan negara sebagai bentuk partisipasi masyarakat, dalam pelaksanaannya telah dirintis sejak zaman Orde Baru melalui inpres No. 1 tahun 1989 tentang pengawasan melekat, didalamnya memuat definisi pengawasan masyarakat sebagai pengawasan yang dilakukan oleh warga masyarakat, disampaikan secara lisan atau tertulis kepada aparatur pemerintah yang berkepentingan, berupa sumbangan pikiran, saran, gagasan atau keluhan/pengaduan yang bersifat membangun yang disampaikan baik secara langsung maupun melalui media.

Setelah reformasi bergulir bermunculan perundangan-undangan memperkuat memberikan payung hukum bagi pengawasan dari masyarakat; dalam UU No. 25 Tahun 2009 tentang Pelayanan Publik; No. 13 Tahun 2009 tentang Pedoman Peningkatan Kualitas Pelayanan Publik dengan Partisipasi Masyarakat; UU No. 28 Tahun 1999 Tentang Penyelenggara Negara yang Bersih dan Bebas dari KKN; Pasal 9 UU No. 28 tahun 1999 dan pasal 34 UU No. 26 tahun 2000 mengatur jaminan perlindungan hukum pada masyarakat sebagai saksi. Sebagai akomodasi hak asasi masyarakat dalam partisipasi masyarakat dalam pembangunan dan penyelenggaraan negara yakni hak untuk mengawasi, hak atas informasi, hak untuk berpendapat dan melakukan pengaduan serta hak perlindungan saksi.

Dalam mengefektifkan pengawasan masyarakat ada dua hal mutlak, yakni pintu keterbukaan dari sistem/intrumen/payung hukum yang ditopang oleh struktur pemerintahan, dan yang paling vital adalah kesadaran serta kemampuan dari masyarakat untuk melakukan pengawasan.

Untuk perundangan telah disebut di atas sebagai payung hukum untuk memasuki sistem pemerintahan 
diharapkan tidak ada jurang pemisah yang besar antara yang diperintah dan pemerintah dalam hal pengawasan pengelolaan dan pembangunan negara, sedang struktur dalam pemerintahan masyarakat bisa menyalurkan aspirasinya melalui Musrenbang untuk tingkat Kecamatan, BPD, LPM, Ombudsman, Kementrian Dalam Negeri, Bawasda, Bappeda, Media Massa, Partai Politik, Lembaga Adat, Media Sosial dan lainnya.

Pelaksanaan fungsi partai politik sebagai agen rekrutmen politikpun (pintu pencalonan) belum berjalan optimal dalam menghasilkan calon yang berkualitas sebagaimana harapan masyarakat. Pencalonan lewat partai politik masih dominan nuansa oligarki elit politik dan kecenderungan memilih calon berdasarkan ukuran materi. Bahkan di sejumlah pemilihan umum sering kali konflik terjadi dalam proses pencalonan. Dalam sejumlah kasus, konflik dipicu oleh calon yang ditentukan oleh elit partai politik di tingkat pusat, namun ditolak oleh para fungsionaris partai politik di daerah. Disejumlah pemilihan legislatif lainnya konflik dipicu calon di luar kader partai politik yang bersangkuan.

Disamping itu, menyimak perkembangan partai-partai politik di indonesia semenjak kejatuhan reszim orde baru pada awal tahun 1998 memperlihatkan bahwa partai-partai politik didirikan sebelum pemilihan umum tahun 1999 dan sebelum pemilihan umum tahun 2004 sulit untuk diharapkan akan mampu mendefinisikan mekanisme demokratis dan trasparan sebagaimana diamanahkan oleh UU Nomor 32 tahun 2004," Untuk memasuki wilayah partai politik dan memendang bahwa porsoalan tersebut sepenuhnya menjadi wewenang partai politik masing-masing".

Politik hukum pembaruan sistem Pemilihan Umum (Pemilu) dengan sistem proporsional telah terbukti banyak membawa pakta. Rakyat dikecewakan dengan perilaku wakil rakyat yang tidak aspiratif dan responsif, dalam beberapa hal bekerja untuk kepentingannya sendiri. Partai politik mempunyai peran yang sangat menentukan, tetapi tidak bertanggung jawab. Hal ini yang mendorong masyarakat untuk melakukan pengawasan terhadap pelaksanaan pemilu Legislatif 2014 di Kelurahan Sapuka Kecamatan Liukang Tangaya Kabupaten Pangkep.

Dari uraian di atas penulis tertarik melakukan Penelitian Mengenai "Pengawasan Masyarakat Terhadap Pemilu Legislatif Tahun 2014 Di Kelurahan Sapuka Kecamatan Liukang Tangaya.

\section{B. KONSEP PENGAWASAN}

Pengawasan menurut Sujanto (Anggriani:2012) adalah segala usaha atau kegiatan untuk mengetahui dan menilai kenyataan yang sebenarnya mengenai pelaksanaan tugas atau kegiatan apakah telah sesuai dengan semestinya atau tidak. Jadi tujuan pengawasan dalam hal ini adalah: (1) Sebagai suatu tindakan pencegahan, agar tidak terjadi suatu yang tidak diinginkan, jadi pengawasan itu tidak harus setelah terjadinya atau adanya dugaan akan terjadi suatu tindak pidana atau pelanggaran; (2) Untuk mengetahui terjadinya pelanggaranpelanggaran terhadap peraturanperaturan yang telah dibuat oleh Negara. Menurut Schemerhom (2007) pengawasan adalah proses dalam menetapkan ukuran kinerja dan pengambilan tindakan yang dapat 
mendukung pencapaian hasil yang diharapkan sesuai dengan kinerja yang telah ditetapkan tersebut. Menurut Stoner, Freemen dan Gilbert (2007) pengawasan adalah proses untuk memastikan bahwa segala aktifitas yang terlaksana sesuai dengan apa yang telah direncanakan. Menurut Winardi (2002) Pengawasan adalah semua aktivitas yang dilaksanakan oleh pihak manajer dalam upaya memastikan bahwa hasil aktual sesuai dengan hasil yang direncanakan.

Sedangkan menurut Basu Swasta (2007) pengawasan merupakan fungsi yang menjamin bahwa kegiatankegiatan dapat memberikan hasil seperti yang diinginkan. Lebih lanjut menurut Terry (Winardi, 2002) juga berpendapat tentang pengertian pengawasan ini, ia mengatakan bahwa: pengawasan berarti mendeterminasi apa yang dilaksanakan, maksudnya mengevaluasi prestasi kerja dan apabila perlu menerapkan tindakantindakan korektif sehingga hasil pekerjaan sesuai dengan rencana. Adapun fungsi pengawasan antara lain: (1) Mempertebal rasa tangung jawab dari masyarakat yang diserahi tugas dan wewenang dalam pelaksanaan pekerjaan; (2) Mendidik masyarakat agar melaksanakan pekerjaannya sesuai dengan prosedur yang telah ditetapkan; (3) Mencegah terjadinya kelalaian, kelemahan,

dan penyimpangan agar tidak terjadi kerugian yang tidak diinginkan; dan (4) Memperbaiki kesalahan dan penyelewengan agar dalam pelaksanaan pekerjaan tidak mengalami hambatan dan pemborosan-pemborosan.

\section{Bentuk-bentuk Pengawasan}

a. Pengawasan Langsunng

Pengawasan langsung adalah pengawasan yang dilakukan dengan cara mendatangi dan melakukan pemeriksaan di tempat terdapat objek yang diawasi.

b. Pengawasan Tidak Langsung

Pengawasan tidak langsung adalah merupakan kebalikan dari pengawasan langsung. Jadi pengawasan tidak langsung dilakukan dengan tanpa mendatangi tempat pelaksanaan pekerjaan atau objek yang diawasi, atau tegasnya dilakukan dari jarak jauh, yaitu "dari belakang meja". Caranya ialah dengan mempelajari dan menganalisis segala dokumen yang menyangkut objek yang diawasi. Dokumen-dokumen itu antara lain dapat berupa: (1) Laporan dari hasil pekerjaan; (2) Laporan hasil pemeriksaan; (3) Surat-surat pengaduan; (4) Berita atau artikel di media massa.

\section{Pengawasan Masyarakat.}

Pengawasan masyarakat adalah pengawasan yang dilakukan oleh warga masyarakat yang disampaikan secara lisan atau tulisan kepada aparatur pemerintah yang berkepentingan, berupa sumbangan pikiran, saran, gagasan atau keluhan/pengaduan yang bersifat membangun yang disampaikan baik secara langsung maupun melalui media.

Istilah masyarakat dalam bahasa Inggris disebut society, sedangkan dalam bahasa arab disebut syareha artinya ikut berpartisipasi dan bergaul. Istilah sosiologisnya disebut berinteraksi. Masyarakat merupakan suatu sistem sosial atau kesatuan hidup yang mempunyai banyak faktor dalam pembentukannya (Arifin:2010). Menurut Selo sumarja (Arif:2010) masyarakat adalah orang-orang yang hidup bersama yang menghasilkan kebudayaan. 
Menurut Koentjaraningrat (dalam Arif: 2010) masyarakat adalah kesatuan hidup manusia yang berinteraksi menurut suatu sistem adat istiadat tertentu yang bersifat kontinyu dan terikat oleh suatu rasa identitas yang sama.

Menurut Ralph linto (Arif: 2010) masyarakat adalah setiap kelompok manusia yang hidup dan bekerja sama dalam waktu yang relatif lama dan mampu membuat keteraturan dalam hidup bersama dan mereka menganggap sebagai satu kesatuan sosial.

Menurut Smith, Stanliy, dan Shores (Arif: 2011) masyarakat adalah sebagai suatu kelompok individuindividu yang teroganisasi serta berpikir tentang diri mereka sendiri sebagai suatu kelompok yang berbeda.

\section{Manfaat Pengawasan Masyarakat}

Penilaian terhadap keberhasilan suatu jasa pelayanan dapat dilakukan dengan tajam oleh penerima jasa pelayanan itu. Seperti tertib/baik tidaknya perawatan di rumah sakit dirasakan terutama oleh pasien yang menerima perawatan itu. Demikian pula berhasil tidaknya pelaksanaan tugas umum aparatur pemerintahan melayani dan mengayomi kepentingan masyarakat sebagaimana yang diamanatkan GBHN, terutama dirasakan oleh masyarakat penerima jasa pelayanan dan pengayoman itu. Hasil Pengawasan Masyarakat yang disamapaikan oleh masyarakat karenanya harus diterima oleh pemimpin sebagai masukan/informasi untuk menilai apakah pelaksanaan tugas aparatur/bawahannya terarah pada tujuan yang telah ditetapkan.

\section{Pemilihan Umum}

Pemilihan umum adalah proses substansial dalam penyegaran suatu pemerintahan. Andrew reynolds (2001) menyatakan bahwa pemilihan umum adalah metode yang di dalamnya suara-suara yang diperoleh dalam pemilihan diterjemahkan menjadi kursi-kursi yang dimenangkan dalam parlemen oleh partai-partai dan para kandidat. Pemilihan umum merupakan sarana penting untuk memilih wakilwakil rakyat yang benar-benar akan bekerja mewakili mereka dalam proses pembuatan kebijakan negara.

Pemilihan umum diikuti oleh partai-partai politik. Partai-partai politik mewakili kepentingan spesifik warga negara. Kepentingankepentingan seperti nilai-nilai agama, keadilan, kesejahteraan, nasionalisme, antikorupsi, dan sejenisnya kerap dibawakan partai politik tatkala mereka berkampanye. Sebab itu, sistem pemilihan umum yang baik adalah sistem yang mampu mengakomodasi kepentingankepentingan yang berbeda ditingkat masyarakat, agar terwakili dalam proses pembuatan kebijakan negara di parlemen. Sebelum dilakukan kajian lebih jauh seputar sistem pemilihan umum, ada baiknya kita telusuri definisi dari sistem pemilihan umum dari sejumla hahli.

\section{METODE PENELTIAN}

Jenis penelitian ini adalah metode penelitian kualitatif yaitu metode penelitian yang digunakan untuk meneliti pada kondisi objek alamiah, sebagai lawannya adalah eksperimen , dimana penelitian adalah sebagai instrumen kunci, teknik pengumpulan data dilakukan adalah observasi dan wawancara. Tipe penelitian ini adalah penelitian yang bersifat deskriptif dengan pendekatan kualitatif yaitu penelitian yang menggambarkan mengenai situasi-situasi atau kejadiankejadian secara sistematis, fakta dan akurat mengenai fakta-fakta 
pengawasan masyarakat terhadap pelaksanaan pemilu legislatif 2014 Kecamatan Liukang Tangaya Kabupaten Pangkep.

Semua data yang diperoleh melalui dokumentasi merupakan informasi yang dapat dijadikan nara sumber data, karena dianggap menguasai bidang permasalahan dan berhubungan erat dengan pelaksanaan seluruh kegiatan untuk mempermudah penyelesaian masalah dalam penelitian. Jenis sumber data yang digunakan dapat dibedakan menjadi. Yaitu data yang diperoleh secara langsung pada saat kita melakukan penelitian. Sumber data yang diperoleh secara langsung dari orang-orang atau responden yang secara sengaja dipilih untuk memperoleh data-data atau informasi yang ada relefansinya dengan permasalahan penelitian.

Data sekunder adalah data yang diperoleh peneliti bersumber dari bahan bacaan atau dokumentasi yang berhubungan dengan objek penelitian. Yang menjadi data sekunder peneliti diantaranya adalah buku paket, undang-undang dan internet maupun data dari instansi terkait.

Teknik pengumpulan data dalam penelitian ini adalah Wawancara merupakan teknik pengumpulan data yang dilakukan dengan tanya jawab antara peneliti dengan informan yang telah dijadikan sumber data. Wawancara dilakukan dengan maksud untuk memperoleh informasi secara langsung dari Informan, adapun Instrumen yang digunakan adalah pedoman wawacara, alat perekam dan kamera. Penentuan informan didasarkan pada pertimbangan kemampuan informan dalam memberikan data-data yang diperlukan sesuai dengan rumusan masalah dan tujuan penelitian.

\section{HASIL DAN PEMBAHASAN}

\section{Pengawasan Masyarakat Terhadap Pelaksanaan Pemilu Legislatif Tahun 2014 Di Kalurahan Sapuka Kecamatan Liukang Tangaya Kabupaten Pangkep}

Pelibatan dan Partisipasi Masyarakat dalam Pengawasan Pemilu. Pelibatan masyarakat menunjukkan satu kewajiban Bawaslu sebagai fungsi yang terlembaga dalam pengawasan pemilu, sedangkan partisipasi masyarakat lebih pada penggunaan hak warga negara untuk mengawal hak pilihnya. Namun, pelembagaan pengawasan itu tidak serta-merta mengambil hak warga negara untuk melakukan fungsi kontrolnya dalam menjaga suara atau kedaulatan rakyat.

Berdasarkan kriteria yang telah disusun dalam bahasan sebelumnya, bisa menekankan pada dua tahapan penting yakni pertama penetapan Daftar Pemilih Tetap (DPT) dan tahapan pemungutan-penghitungan suara. Mulai pemilihan hingga penetapan hasil pemilu. Kedua tahapan ini dianggap penting, karena terkait langsung dengan hak pemilih untuk bisa menggunakan suaranya. Penetapan DPT sebagai salah satu isu krusial yang sering diperdebatkan baik dalam proses hingga saat penetapan hasil pemilu. Begitu juga dengan tahap pemungutan dan penghitungan suara.Tahap ini paling menentukan yakni sebagai inti dari semua tahapan pemilu. Selain itu, tahap pemungutan dan penghitungan suara rawan terjadinya penyimpangan. (Marsuki Kadir).

Fungsi pengawasan intern oleh KPU dilengkapi dengan fungsi pengawasan ekstern yang dilakukan oleh Bawaslu serta Panwaslu Provinsi, 
Panwaslu Kabupaten/Kota, Panwaslu Kecamatan, Pengawas Pemilu Lapangan, dan Pengawas Pemilu Luar Negeri. Pembentukan Pengawas Pemilu tersebut tidak dimaksudkan untuk mengurangi kemandirian dan kewenangan KPU sebagai penyelenggara pemilu. Dengan adanya pengawasan terhadap penyelenggara pemilu dari dalam dan dari luar lembaga penyelenggara diharapkan pemilu dapat terlaksana dengan demokratis dan memenuhi asas pemilu.

Penyusunan Daftar Pemilih Tetap yang disusun oleh KPU dan KPPS itu tersususn dengan rapi tidak ada pelanggaran yang ditemukan, dan tidak laporan dari masyarakat. Begitupun Pemungutan dan Perhitungan Suara itu khusus di Kelurahan Sapuka. Pengawasan yang dilakukan oleh masyarakat ada lima yang harus diawasi diantaranya : (1) Pemantau (2) penyampaian Laporan Awal dan atau Informasi Awal temuan dugaan pelanggaran (3) Kajian (4) Kampaye Pengawasan dan (5) Bentuk lain yang tidak melanggar ketentuan perundangundangan.

Menurut Ketua KPU Kabupaten Pangkep bahwa tidak ada pelanggaran yang ditemukan dalam proses pelaksanaan pemilu di Kelurahan Sapuka, baik itu Daftar Pemiih Tetap, Kampanye, Pemungutan Suara dan Perhutungan Suara. Dari Daftar Pemilih Tetap KPU Kabupaten Pangkep telah mengelesaikan DPT bersama PPK untuk mengunpulkan semua hasil rakapitulasi dari Dakftar pemilih Samentara menjadi Daftar Pemilih Tatap. Hal ini sesuai dengan hasil wawancara peneliti dengan informan yakni:

"Proses pelaksanaan pemilu, mulai dari Daftar Pemilih
Tetap, Kampanye, Pemungutan

Suara dan Perhitungan kami tidak menemukan pelanggaran yang terjadi, karna semua proses pelaksanaan pemilu dikerjakan dengan penuh rasa tanggung jawab oleh para penitia pelaksana pemilu". (wawancara JP).

Pelaksanaan pemilu di Kelurahan Sapuka, baik dari pengawsan langsung maupun pengawasan tidak langsung, masyarakat tidak menemukan persoalan di dalam pelaksanaan pemilu baik dari Daftar Pemilih Tetap, Kampanye, Pamungutan Suara dan Perhitungan Suara semuanya berjalan dengan tertib tidak di temukan oleh masyarakat pelanggaran yang begitu berarti. Adapun pengawasan yang dilakukan oleh masyarakat terhadap tahap-tahap pemilu antara lain:

1) Kampanye

Pada tahap kampanye para calon anggota legisltaif melakukan kegiatan meyakinkan para pemilih dengan menawarkan visi, misi, dan program peserta pemilu. Pemetaan pelanggaran dan penekanan pada prioritas pencegahan akan memudahkan masyarakat dalam mendorong pelibatan dan partisipasi pemilih.

Pengawasan yang dilakukan oleh Bawaslu memiliki tantangan yang sangat besar. Tantangan itu terkait dengan peta persoalan yang akan muncul, seperti politik uang,kompetisi antar-partai politik, dan bahkan antarcaleg dalam satu partai politik. Kompetisi yang begitu kuat akan berpotensi memunculkan banyak penyimpangan yang harus diantisipasi oleh Bawaslu.

Menjawab persoalan dan tantangan tersebut, memang tidak bisa hanya dilakukan melalui mekanisme 
yang selama ini berlangsung.Bawaslu mesti membuat inovasi dan terobosan sehingga bisa menutup kelemahankelemahan yang ada. Bawaslu tidak bisa menjalankan tugasnya sendiri, tetapi juga harus melibatkan publik dan mendorong partisipasi publik yang lebih efektif.

Gempuran pragmatisme elite ini merupakan tantangan yang paling berat dalam mendorong partisipasi masyarakat. Pemilih sudah dikapitalisasi, dimana politik uang telah menyebabkan apatisme warga tinggi. Tantangannya adalah melawan apatisme warga dan serangan kandidat yang gemar berpolitik uang.

Meskipun

gempuran pragmatisme politik cukup kuat, ternyata sesungguhnyamasih cukup banyak kelompok yang memiliki kepedulian dan kesadaran kritis keluar dari gempuran itu. Pelibatan masyarakat dalam diskusi ini tidak didasarkan pada orientasi uang, karena mereka secara sukarela dan memahami pentingnya forum tersebut sebagai upaya partisipasi.

Sebelum mendorong pelibatan masyarakat dalam proses pengawasan, meskipun secara sadar ternyata tantangan itu juga muncul dari regulasi yang tidak berpihak dan anggaran yang kurang mendukung. Terkait regulasi, misalnya, pelaporan pelanggaran sebagai tindaklanjut pengawasan/pemantauan hanya bisa dilakukan oleh pemilih. Oleh karena itu, dalam setiap laporan dugaan pelanggaran, pelapor akan ditanyakan apakah sudah terdaftar atau belum.

2) Pemungutan Suara

Masyarakat harus secara sadar dan terencana mengalihkan perhatiannya kepada pemilih dan kelompok yang cenderung nonpartisan. Pemilih harus didekati, dimu- dahkan upayanya untuk turut berpartisipasi, dijamin haknya sebagai pemilih serta diberikan perlindungan agar turut berpartisipasi atau bahkan menginisiasi kekuatan besar untuk menghalau penyimpangan pemilu. Kekuatan pemilih yang cukup besar dengan sebaran wilayah merata bisa menutup kelemahan pengawas pemilu dalam menjalankan tugas pengawasan. Dalam mendorong upaya tersebut, Bawaslu mesti memulai merangkul aktor-aktor yang mendukung, kerjasama dengan beberapa aktor dan menyesuaikan dengan peran utama masing-masing lembaga.Seperti kerjasama dengan penggiat pemilu, universitasuniversitas, dan kelompok masyarakat dengan tujuan agar ada dukungan terhadap upaya Bawaslu dalam melakukan pencegahan. Hal ini sebenarnya sudah dilakukan dengan cukup intensif.

3) Perhitungan Suara

Menyentuh kesadaran kolektif pemangku kepentingan baik penyelenggara maupun peserta pemilu diyakini tidak mudah. Penyelenggara pemilu berpeluang melakukan kesalahan akibat penyalahgunaan kekuasaan atau bahkan karena kelalaian. Begitu juga dengan peserta, pemaknaan pemilu sebagai kompetisi justru akan menjebak mereka pada ruang pertarungan bebas antar kandidat.

Penyelenggara Pemilu mesti menjalankan tugas dan kewajibannya dengan baik. Begitu juga dengan peserta pemilu untuk mematuhi aturan main. Jika kesadaran kolektif pemangku kepentingan bisa diwujudkan, maka dapat dipastikan bahwa pemilu akan berjalan secara demokratis. Pelanggaran pemilu yang 
sering muncul dalam periode-periode sebelumnya akan diminimalisir.

Menyentuh kesadaran kolektif pemangku kepentingan baik penyelenggara maupun peserta pemilu diyakini tidak mudah. Penyelenggara pemilu berpeluang melakukan kesalahan akibat penyalahgunaan kekuasaan atau bahkan karena kelalaian. Begitu juga dengan peserta, pemaknaan pemilu sebagai kompetisi justru akan menjebak mereka pada ruang pertarungan bebas antarkandidat. Jika ini terjadi, pelanggaran dan kecurangan tidak bisa terelakkan. Hal ini sesuai dengan pernyataan informan yakni:

"Dalam pemilihan calon legislatif di Kelurahan Sapuka yang sangat penting untuk diawasi itu ada empat (1) Penyelenggara (2) Pemilih (3) peserta pemilu dan (4) masyarakat itu sendiri. Dari semua itu masyarakat melakukan pengawasan dengan baik dengan cara mendaftarkan dirinya menjadi anggota KPPS, Panwas, Panwascam, dan panitia TPS". (wawancara TM)

Berdasarkan

prioritas pengawasan tersebut, maka masyarakat tidak akan dituntut atas sesuatu yang tidak menjadi kewenangannya, seperti upaya penindakan. Otoritas yang ada bisa memaksimalkan upaya untuk mencegah terjadinya pelanggaran Pemilu. Pencegahan yang efektif diyakini akan menjadi sumber dan awal berjalannya pemilu yang demokratis.

Untuk menguatkannya, orientasi pengawasan ini adalah menjamin integritas penyelenggaraan dan terlaksananya hak politik warga. Selain itu, pelaksanaan tugas pencegahan yang efektif diharapkan mampu meminimalisir terjadinya pelanggaran.

Pengawasan dan pemantauan pemilu merupakan satu bagian dari upaya kontrol terhadap proses penyelenggaraan pemilu. Keduanya merupakan satu fungsi yang sama sebagai upaya mengawal penyelenggaraan pemilu yang jujur dan adil. Namun, perbedaan itu lahir akibat pelembagaan yang mengupayakan kontrol terhadap penyelenggara pemilu. Pelembagaan fungsi kontrol ini muncul akibat maraknya bentuk pelanggaran dan kecurangan dalam Pemilu, yakni manipulasi penghitungan suara oleh petugas pemilu. Atas persoalan itu, pengawasan masyarakat sangat diperlukan.

\section{Pengawasan Tidak Langsung}

Disamping pengawasan oleh Bawaslu, terdapat juga pengawasan yang dilakukan oleh masyarakat terhadap proses penyelenggaraan pemilu yang disebut dengan kegiatan pemantuan pemilu. Adanya partisipasi masyarakat dalam melakukan pengawasan pemilu ini adalah bentuk dari penggunaan hak warga negara untuk mengawal hak pilihnya. Kemudian, kegiatan pemantauan ini juga merupakan upaya kontrol dari publik untuk menjaga suara dan kedaulatan rakyat di dalam penyelenggaraan Negara.

Masing-masing posko dilengkapi spanduk, papan media informasi dan kotak pengaduan masyarakat. Posko menyediakan layanan masyarakat untuk mendukung proses pendidikan pemilih yang berupa informasi penting untuk diketahui masyarakat luas (berita), informasi hasil pemantauan melalui pesan layanan singkat, dan ko- 
ordinasi para relawan yang bekerja di lapangan.

Ini merupakan tempat yang berlokasi di Kabupaten/Kota yang berfungsi menyediakan informasi pemilu dan konsolidasi dengan posko di Kecamatan, serta advokasi masyarakat di wilayah masing-masing. Pendekatan dalam pendayagunaan kantor sekretariat menerapkan bentuk partisipasi yang komunikatif dan responsif. Hal ini sesuai dengan pernyataan innforman yakni:

"Pengawsan yang kami lakukan sebagai Panwaslu, juga tidak menemukan pelanggaran terhadap proses pelaksanaan pemilu baik dari Daftar Pemilih Tetap, Kampanye, Pemungutan Suara maupun Perhitungan semuanya berjalan dengan lancar, dengan kata lain pengawasan yang kami lakukan bersama teman-teman itu kami jalankan sesuai dengan UU Pengawas Pemilu". (wawancara SY)

Penguatan

kelembagaan pengawas pemilu inilah yang membedakan dengan fungsi pengawasan yang dilakukan masyarakat.Hasil pengawasan masyarakat tidak serta-merta bisa ditindaklanjuti, karena hanya lembaga pengawas pemilu yang berwenang menerima laporan masyarakat dan menindaklanjutinya. Disinilah perbedaan yang menonjol antara pengawasan dengan pemantauan. Pengawasan merupakan bagian dari fungsi kontrol penyelenggaraan pemilu yang dilembagakan, diberikan hak dan kewenangan untuk mengawasi, menerima laporan masyarakat dan menindaklanjuti.
Pengawasan yang dilakukan oleh masyarakat ternyata hanya ada satu partai politik saja yang melakukan kampanye, pemilihan calon legislatif yang demokratis mengharuskan adanya lembaga pengawas yang independen dan otonom. Namun demikian, pengawasan dari masyarakat juga sangat dibutuhkan agar pemilu legislatif berjalan sebagaimana yang diharapkan. Hal ini didasarkan pada suatu realita yang dihadapi oleh Panwas selama ini, yakni: (1) terbatasnya jumlah anggota Panwas; (2) problem kapasitas anggota Panwas; (3) teknologi modern; (4) problem hubungan komunikasi antar lembaga penyelenggara.

Partisipasi yang dilakukan oleh masyarakat dalam pemilihan legislatif ternyata tidak ditemukan titik permasalahan. Berdasarkan praktek penyelenggaraan pemilu di Indonesia selama ini, penyelenggaraan pemilu kerap memunculkan masalah-masalah penegakan hukum. Situasi ini disebabkan tidak lain karena peluang untuk terjadinya pelanggaran sangat terbuka, baik pelanggaran yang dilakukan oleh penyelenggara pemilu, peserta pemilu (partai politik, pasangan calon, maupun perseorangan), tim kampanye, pemerintah, pemilih, serta masyarakat umum. Oleh karenanya, pengawasan pemilu juga dilakukan melalui kegiatan mengkaji prospek-prospek tertentu yang diduga berpotensi terjadinya pelanggaran pemilu. Pelanggaran tersebut dipaparkan oleh salah satu informan yakni:

Pelanggaran pemilu dibagian kampanye, ada tim sukses caleg yang melakukan money polityc yaitu, dengan menjanjikan sesuatu kepada masyarakat untuk memperoleh suara 
terbanyak dan masyarakat hanya bisa menerima apa yang dijanjikan/menyetujui tawaran caleg tersebut tampa ada pertimbangan". (wawancara $\mathrm{HJ}$ )

Pengawasan pemilu sebagai kegiatan memeriksa, dapat diartikan pula sebagai kegiatan "melihat, mencermati, dan memperoleh" laporan atau bukti-bukti yang menjadi indikasi awal dugaan pelanggaran pemilu. Dalam konteks ini, pengawasan pemilu harus bersifat fact finding, yakni menemukan fakta-fakta yang menjadi indikasi awal dugaan pelanggaran pemilu melalui teknik pengawasan.

Penyelenggaraan pemilu yang demokratis seharusnya dijalankan sesuai dengan asas pemilu yang dianut Indonesia yaitu Luber dan Jurdil .Agar asas pemilu Luber dan Jurdil dapat terlaksana dilakukan pengawasan. Pengawasan tersebut bukan hanya dilakukan oleh Panwaslu saja, kita juga harus berperan dalam pengawasan tersebut. Masyarakat dapat melakukan pemantauan baik secara langsung maupun tidak langsung dalam proses berjalannya demokrasi/Pemilu. Pemantauan langsung bisa dilakukan pada saat proses demokrasi berlangsung misalnya dalam proses pencoblosan, penghitungan, pendistribusian suara. Serta pemantauan tidak langsung yang dilakukan dalam proses pra demokrasi berlangsung misalnya, pemasangan media/atribut kampanye.

Pengawasan yang dilakukan oleh masyarakat yang ada di Kecamatan Liukang Tangaya, baik pengawasan secara langsung maupun pengawasan tidak langsung semuanya sudah efektif karena, semua proses pelaksanaan pemilu masyarakat ikut berpartisifasi, baik jadi Panwas, PPL, KPPS, sempai yang bertugas di TPS itu semua dari masyarakat pulau sapuka.

$$
\text { Menegaskan }
$$

pengertian

pengawasan dalam lingkup pemantauan, sebagai aktivitas memastikan proses tahapan-tahapan pemilu dengan cara mengumpulkan data, informasi serta menginventarisasi temuan kasus terkait pelaksanaan pemilu yang dilakukan oleh kelompok masyarakat atau organisasi yang independen dan non partisan.

\section{E. PENUTUP}

Berdasarkan hasil penelitian dan analisis yang dilakukan maka, peneliti berkesimpulan sebagai berikut:

1) Pengawasan masyarakat terhadap pemilu legislatif 2014, melalui pengawasan langsung dilakukan dengan cara mendatangi dan melakukan pemeriksaan di tempat terdapat objek yang diawasi seperti: DPT, Kampanye, Pemungutan Suara dan Perhitungan Suara;

2) Pengawasan tidak Langsung yaitu dilakukan dengan tapa mendatangi tempat pelaksanaan pekerjaan atau objek yang diawasi yaitu mengakses dokumen-dokumen pelaksanaan pemilu melalui panitia pelaksana pemilu.

Berdasarkan kesimpulan diatas maka penulis mengajukan beberapa saran sebagai bahan pertimbangan kedepannya yakni:

1. Sebaiknya pemilu dijalankan dengan demokratis dan diperlukan pengawasan dalam proses pemilu tersebut.Masyarakat dalam memilih juga harus lebih hati-hati, jangan karena diberi iming-iming oleh satu peserta kita memilih dia;

2. Pemerintah harus memberikan ruang kepada masyarakat untuk melakukan pengawasan. Sehingga 
praktik kecurangan dapat diminimalkan.

3. Pemerintah harus trasparansi agar masyarakat muda untuk melakukan pengawasan.

\section{DAFTAR PUSTAKA}

\section{Buku}

Arifin, Zainal. 2010. Ilmu Sosial Budaya Dasar:Anungrah Mandiri.

Abdul Latif, Hasbi Ali. 2014. Politik Hukum, Jakarta : Sinar Grafika

Anggriani, Jum. 2012. Hukum Administrasi Negara, Yogyakarta; Graha Ilmu.

Bohari. 1995. Pengawasan Keuangan Negara, Jakarta : PT Raja Grafindo Persada.

Miriam. Budiardjo, 2004 Dasar-Dasar Ilmu Politik. Jakarta: PT. Gramedia Pustaka Utama.

Matias Iaryczower and Andrea Mattozzi, 2008 "Ideology and Competence in Alternative Electoral Systems", Paper, Division of Humanities and Social Sciences, California Institute of Technology, Pasadena, California.

Nohlen, Dieter. 2008 "Electoral Systems" dalam Lynda Lee Kaid and Christina HoltzBacha, Encyclopedia of political communication, California: Sage Publications.

Nawawi, Hadari. 1989 Pengawasan Melekat Di Lingkungan Aparatur Pemerintah. Jakarta : Ciraca

Peraturan Badan Pemilihan Umum Nomor 14 tahun 2012, Tentang penanganan pelanggaran Pemilihan umum

Santoso Topo dan Didik Supriyanto. 2004. Mengawasi Pemilu Mengawal Demokrasi. Jakarta:
Murai Kencana-PT Raja Gravindo Persada.

Suharzal. 2012. Regulasi, Dinamika, dan Konsep Mendatang, Jakarta : Rajawali Pers.

Reynolds, Andrew. 2001 "Merancang Sistem Pemilihan Umum" dalamJuanJ.Linz, et.al., Menjauhi Demokrasi Kaum Penjahat: Belajar dari Kekeliruan Negara-negara Lain, Bandung: Mizan,

Winardi. 2002. Motivasi dan Pemotivasian Dalam Manajemen. Jakarta : PT Grafindo Persada

\section{Internet}

Arif Sobarudin By Written. 2011 pengertian masyarakat menurut para ali http://kesmasunsoed.info/2011/10/definisimasyarakat-menurut-paraahli.html diakses 20 februari 2015

Fitri Heriyanti Pengawasan Partisipatif Pemilu 2013 http://www.riaupos.co/1819opini-pengawasan-partisipatifpemilu.html diakses 21 februari 2015

Hatifah. 2012. Peraturan KPU No. 6 Tahun 2013 tentang Perubahan Keempat Tahapan Pemilu:

http://hetifah.com/artikel/per ubahan-keempat-tahapanjadwal-pemilu-2014.html

Friday,2007.http://definisimu.blogsp ot.com/2012/09/definisipeng awasan.html diakses 22 Februari 2015 